\title{
Noise Pollution; Assessing and Control in the Beet Sugar Industry
}

\author{
Mohamed Abuel- Kasem Mohamed ${ }^{1}$, Mohamed Mahmoud \\ Hafez $^{2}$, Ragab Rabeiy ${ }^{1}$, Essam A, A. El Nagreedy ${ }^{2}$ \\ ${ }^{1}$ Mining and Metallurgy Engineering Department, Faculty of \\ Engineering, Assiut University, Egypt \\ ${ }^{2}$ Dakahlia Sugar and Refining Company, Egypt
}

\begin{abstract}
Protection of the expertise workers in the Sugar production is essential for the sustainability and development of this strategic national industry. Noise pollution is a physical factor that may have negative effects on the employees. In this study, noise levels and control methods are studied in the beet sugar industry in the Dakahlia plants. Inspection of the studied plants presented that noise is emitting from several sources such as beet lab reception, beat washing and slicers, vacuum pump area, centrifugal mixer station, power station and boiler house. Sound Pressure Levels (SPL) of the sources are measured according to ISO recommendation, while noise exposure levels are carried out using equivalent noise level. The results proved that sound pressure level exceeded the national limits assigned by the Egyptian Environmental Law No 4/94. The maximum and minimum values of SPL at boiler soot blower were 110 and 78dBA respectively. In the old Belqase sugar factory, it has been found that the maximum SPL reached to $112 \mathrm{dBA}$ at boiler soot blower and the minimum value was $83 \mathrm{dBA}$ in the air composer. Noise exposure also is assessed to protect the employees in the old and new sugar plants. As the working shift is 12 hours in the investigated plant, a model is used to estimate the equivalent noise dose according to 8 hours exposure. The results revealed that the workers in the old sugar plant are suffering in the high emitted noise levels. Control measures are essential to reduce the noise especially from the old sugar plant.
\end{abstract}

Keywords: Sugar Industry, Exposure Limits, Noise Sources, Noise Exposure. 


\section{Introduction}

The sugar industry uses sugar cane and sugar beet to manufacture edible sugar. Sugar production from beet presents about $40 \%$ from the world sugar production. Beet sugar industry is considered as seasonal sugar production for 18 weeks a year ${ }^{20}$. One of the operations during the processing of sugar beet is depending mainly on the quality of the beet. This process requires washing the beet using high pressure water jets in several washers before slicing and weighing. The noise control act of 1972 spells out federal plans to keep noise at tolerable levels. The federal laws are directed to emissions, but provide technical assistance to states establishing performance laws. The situation is also complicated by an overlapping of authority of the environmental protection agency and the occupational safety and health administration .As battle development over the acceptability of 85 or $90 \mathrm{dBA}$ (decibel is a unit of sound pressure level based on practical scale of $0-140$ $\mathrm{dBA}$ ) as the safe sound level for worker, it became evident that the U.S. Occupational Safety and Health Agency( OSHA) has direct responsibility for worker safety while the environment protection agency ( EPA ) must protect the worker as a plant employee and also as a citizen. Madbuli H. Nower et al (2003) ${ }^{24}$ concluded that the problem of industrial noise had been aggravated by the use of high speed, high production machines in textile mills and other industries. The causal relationship between work place noise and hearing loss has been observed for centuries (Franks, 1988). Recently, there have been many trials for assessing the magnitude of the problem of noise exposure in manufacturing industries. The U.S. Occupational Safety and Health Agency (OSHA), in 1981, estimated that more than 6 million workers (active and retired) had noise exposure levels greater than $85 \mathrm{dBA}$ in the U.S.A (OSHA, 1981). However, Frank (1988) used data of two OSHA conducted U.S. industry-wide noise surveys estimated that some 4.7 million Labor were exposed in 1985 to average daily noise levels of 85 dBA or greater. Meanwhile, a National Occupational Hazard (NIOSH) survey revealed that the top seven industries with the 
greatest percentage of workers exposed to $85 \mathrm{dBA}$ or greater were lumber and wood, textiles, petroleum, utilities, metals, printing and paper production (NIOSH-NOHS 1974, 1977 and 1978). Similar findings were reported by the two OSHA contracted noise surveys (Bolt, et al. 1976; Booz et.al, 1983). In the U.K., noise pollution was reported in $\mathbf{1 9 8 5}$ as the biggest hazard in factories, since 700 000 workers were being still exposed to noise levels exceeding the government's recommended limit of 85 dBA (Pearce, 1985).

This study aimed to evaluate the noise pollution problems that results from beet sugar beet industry, to establish noise pollution control methods. This study was carried out on Belqase sugar plants.

\section{Materials and Methods}

\subsection{Site Description}

Experimental work of this study was carried out in Belkas, AbuMady area. Sugar beet factories are located in this area at 1.5 $\mathrm{m}$ below sea level. The site of the factories is shown in figure (1). The first factory has been established in 1992 and the second factory has been established in 2011.

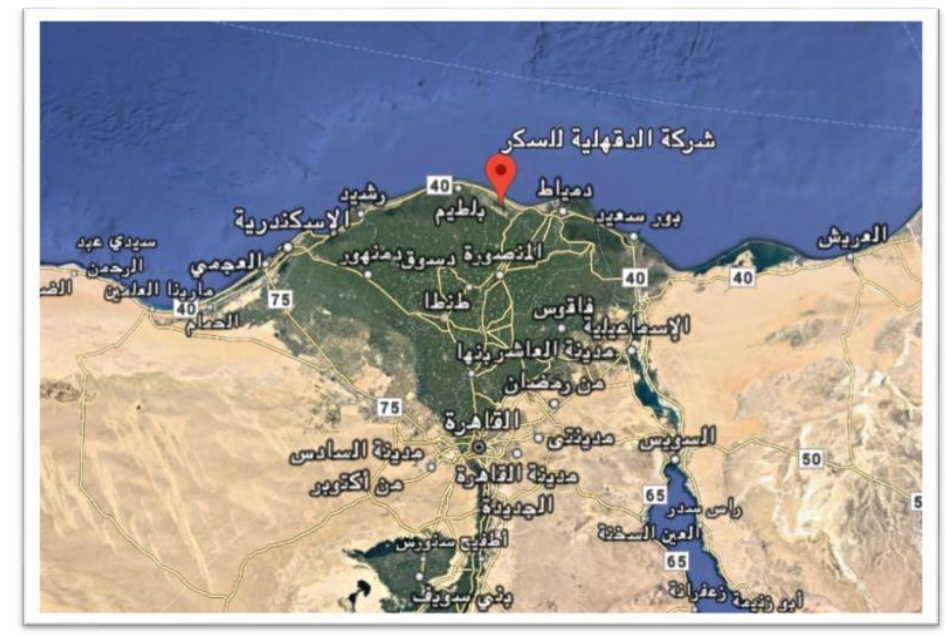

Fig. (1) Site of the experimental work 
Dakahlia sugar and Refinery Company is one of the industrial castles in Africa and the Middle East for production of beet sugar and contributes about $13.65 \%$ of sugar production in $\boldsymbol{E g y p t}^{\mathbf{2 4}}$. The Belkas Sugar Factories produce the white sugar as the main product, molasses and pulpbetizing. Dakahlia sugar and refining company produces white sugar according to Egyptian standard specifications (358/2005) and European standard as presented in Table (1). In addition, Dakhlia Company produces also animal feed (Pulpbeltizing) and molasses as byproduct with the specifications presented in Table (1).

Table (1). Specifications of the white sugar, Pulpbeltizing, and Molasses.

\begin{tabular}{|c|l|l|l|l|l|}
\hline \multicolumn{2}{|c|}{ Sugar Specifications } & \multicolumn{2}{c|}{$\begin{array}{c}\text { Pulpbeltizing } \\
\text { Specifications }\end{array}$} & \multicolumn{2}{c|}{$\begin{array}{c}\text { Molasses } \\
\text { Specifications }\end{array}$} \\
\hline Polarizatio & Min 99.9\% & Humidity & $\mathbf{1 0 \%}$ & Brix & $\mathbf{8 2 \%}$ \\
\hline Humidity & Max 0.03\% & Protein & $\mathbf{7 - 9 \%}$ & Purity & $\mathbf{5 8 . 5 \%}$ \\
\hline $\begin{array}{c}\text { Colour in } \\
\text { solution }\end{array}$ & Max 35 IU & Diameter & $\mathbf{9 - 1 1 ~ m m ~}$ & Sugar & $\mathbf{4 8 \%}$ \\
\hline Ash & $\mathbf{0 . 0 1 5 \%}$ & Sugar & Max 7\% & pH & $\mathbf{8 . 9}$ \\
\hline
\end{tabular}

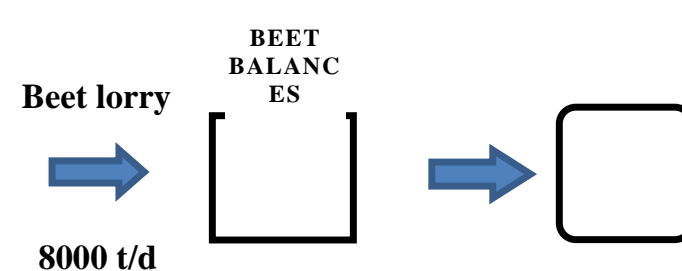

Pulp press

White sugar

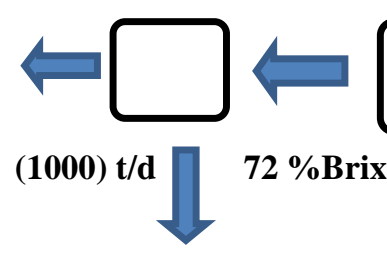

Molasses

Fig. (2). The flow diagram of Belkas Sugar Factory. 
The flow diagram presented in figure (2) explains the process of sugar beet production where the beet passes through several stages. These stages are beet weighing, beet lab reception, washing, and slices. The pulp produced from extraction passes through pulp dryer and pulp press to produce animal feeding (Pulpbeltizing) products. In juice purification station, juice syrup is extracted to produce juice with $17 \%$ Brix. The juice purification passes through evaporation process to increase the concentration of Brix in the juice syrup from $17 \%$ to $72 \%$. In the final process, the concentrated syrup passes through three crystallization units. Cyclones use centrifugal force to separate molasses from the white sugar. The produced sugar is then dried and packed to the consumer.

\subsection{Noise Measurement and Analysis}

For each sugar plant (old and new), noise measurements were carried out at strategic locations depending on the type, number and layout of machines. The noise measurements included Maximum and Minimum SPLs at the individual octave bands. Other relevant data such as the operation, type and number of machinery, construction materials for roofs, floors, walls and ceilings etc. were also recorded. Noise was measured at each location using the Sound Level Meter SL - 4010. It has measurement range (35-130) dBA. The noise was measured at $1 \mathrm{~m}$ from the source and $1.5 \mathrm{~m}$ from the floor. The noise measured at all possible sources. The calibration of the instrument was checked before and after each set of measurements as recommended by the SLM manufacturer (B\&K) multi-function acoustic calibrator, model: 4226. The measurements were taken over duration of $10 \mathrm{~min}$ at each location. The data were statistically analyses using Excel program. For each factory, frequency tables for Max and Min SPL levels were constructed. 


\section{Results and Discussion}

The dBA is the unit used to measure the intensity of sound. Both Max (SPL) and Min (SPL) of the surveyed factories are given in Table (2) and graphically shown in figures (3\&4). The results proved that sound pressure level exceeded the national limits assigned by Egyptian Environmental Law No (4/94) in several sites. The maximum SPL was (110) dBA at boiler soot blower and the minimum value of SPL was (78) dBA in the cooling tower of pump station at the old sugar plant. In the new Belqase sugar factory, it has been found that the maximum SPL reached to (112) dBA at boiler soot blower and the minimum value was (83) dBA in the air composer. Noise exposure also is assessed to protect the employees in the old and new Sugar plants. As the working shift is (12 hours) in our investigated plant, a model is used to estimate the equivalent noise dose according to (8 hours) exposure ${ }^{10,14,16}$. The results presented that the workers in the old Sugar plant are suffering from the high emitted noise levels. Control measures are essential to reduce the noise especially from the old sugar plant. In the Belkase sugar and refining plants, there are suggested and designated the new covering in the soot blower station to decrease the sound level pressure from (110 dBA to $85 \mathrm{dBA}$ ) by adsorption as this drowning figure (5). 


\section{Table (2). Production season 2017 for Dakhlia sugar and} refining old plant and new plant.

\begin{tabular}{|c|c|c|c|c|c|c|}
\hline Station & $\begin{array}{c}\text { Max. } \\
\text { SPL } \\
\text { (dBA) }\end{array}$ & $\begin{array}{l}\text { Max. } \\
\text { SPL } \\
\text { (dBA) }\end{array}$ & $\begin{array}{c}\text { Average. } \\
\text { SPL } \\
\text { (dBA) }\end{array}$ & $\begin{array}{c}\text { Average. } \\
\text { SPL } \\
\text { (dBA) }\end{array}$ & $\begin{array}{c}\text { Min. } \\
\text { SPL } \\
(\text { dBA })\end{array}$ & $\begin{array}{l}\text { Min. } \\
\text { SPL } \\
\text { (dBA }\end{array}$ \\
\hline & old & new & old & new & old & new \\
\hline Beat Lab reception & 87 & 85 & 81 & 80 & 75 & 75 \\
\hline $\begin{array}{l}\text { Beet washing and } \\
\text { Slicers Slicers }\end{array}$ & 90 & 92 & 87.5 & 84.5 & 85 & 77 \\
\hline Vacuum Pump area & 88 & 82 & 88 & 82 & 88 & 82 \\
\hline $\begin{array}{l}\text { Centrifugal mixer } \\
\text { station }\end{array}$ & 88 & 86 & 87.5 & 85.5 & 87 & 85 \\
\hline Power station & 92 & 91 & 80 & 80 & 68 & 69 \\
\hline $\begin{array}{l}\text { Boiler water } \\
\text { treatment }\end{array}$ & 84 & 87 & 77 & 77.5 & 70 & 68 \\
\hline Boilers house & 92 & 95 & 79.5 & 81.5 & 67 & 68 \\
\hline $\begin{array}{l}\text { Boiler house (soot } \\
\text { blower) }\end{array}$ & 110 & 112 & 103.5 & 105.5 & 97 & 99 \\
\hline $\begin{array}{l}\text { Cooling tower pump } \\
\text { station }\end{array}$ & 78 & 85 & 78 & 85 & 78 & 85 \\
\hline Pulp dryer station & 95 & 98 & 85 & 84 & 75 & 70 \\
\hline Lime kiln area & 83 & 85 & 77.5 & 77.5 & 72 & 70 \\
\hline Air compressor area & 87 & 83 & 87 & 83 & 87 & 83 \\
\hline
\end{tabular}

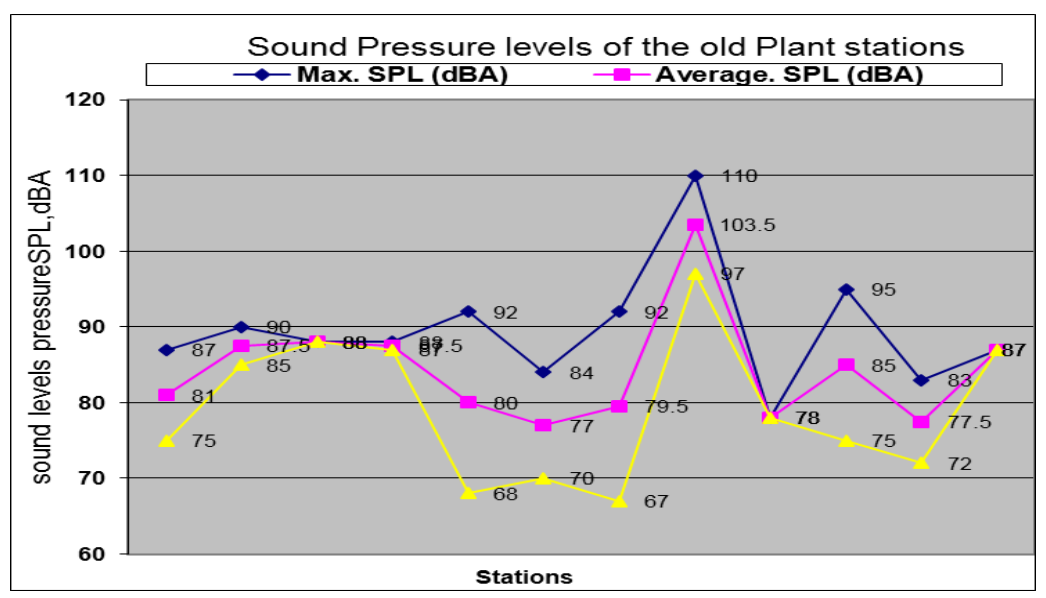

Fig. (3). Measured noise level in Dakahlia Sugar and Refining old plant 


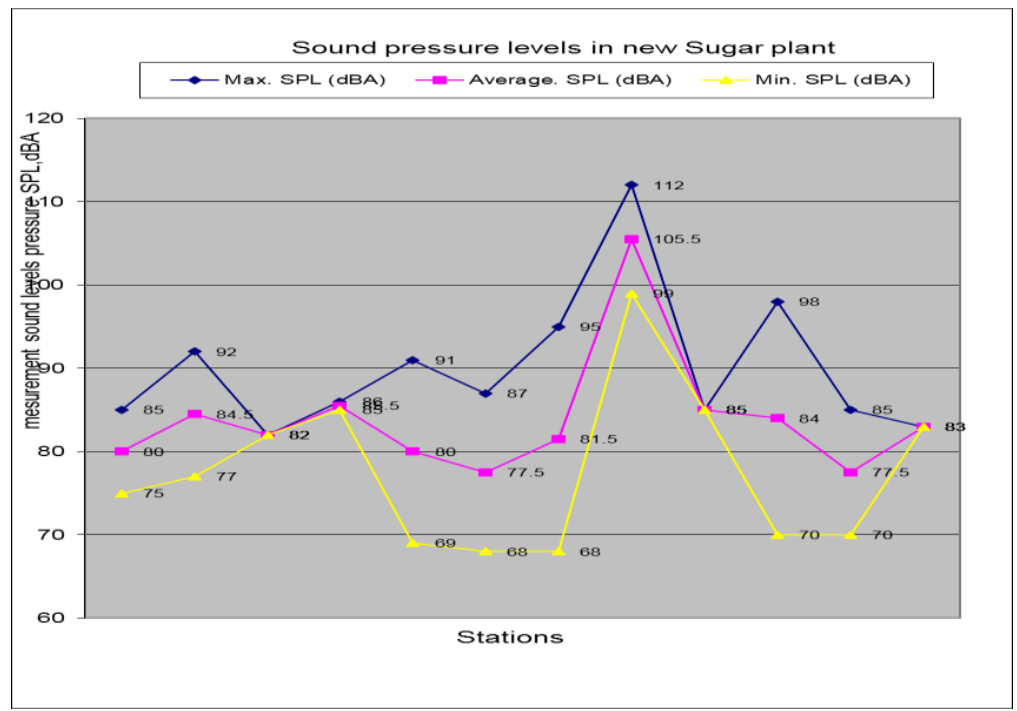

Fig. (4). Measured noise levels in Dakhlia Sugar and Refining new plant

From Fig (3) and Fig (4), Maximum SPL was (112) dBA at boiler soot blower and the minimum value of SPL was (83) dBA from cooling tower pump station. The results proved that sound pressure level exceeded the national limits assigned by Egyptian Environmental Law No (4/94) at five production stations.

Table (3). Workers noise diseases in Dakhlia sugar and refining company

\begin{tabular}{|c|c|c|c|}
\hline $\begin{array}{c}\text { Dakhlia Sugar and } \\
\text { refining company }\end{array}$ & $\begin{array}{c}\text { Operation } \\
\text { Date }\end{array}$ & $\begin{array}{c}\text { Worker Exposure } \\
/ 12 \text { hrs. }\end{array}$ & $\begin{array}{c}\text { Workers Noise } \\
\text { Diseases }\end{array}$ \\
\hline Old plant & 1995 & 323 & 6 \\
\hline New plant & 2011 & 323 & 0 \\
\hline
\end{tabular}

From Table (3) as the working shift is (12 hrs.) in our investigated plant, a model is used to estimate the equivalent noise dose according to (8 hrs.) Exposure as Unified Labor Law (No. 12 of $\left.2003^{1}\right)^{10}$. It is found that the length of exposure time of the workers to the noise gives higher levels of noise than allowed in 
Egyptians labor law and environment. It is found that 6 workers have been got noise diseases in old plant as a result of long periods of noise pollution. This is due to not following the safety and occupation health instructions in the factory and the poor overall maintenance of the equipment and machinery. The results presented that the workers in the old Sugar plant are suffering from the high emitted noise levels. Control measures are essential to reduce the noise especially from the old sugar plant as given in Figure (3).

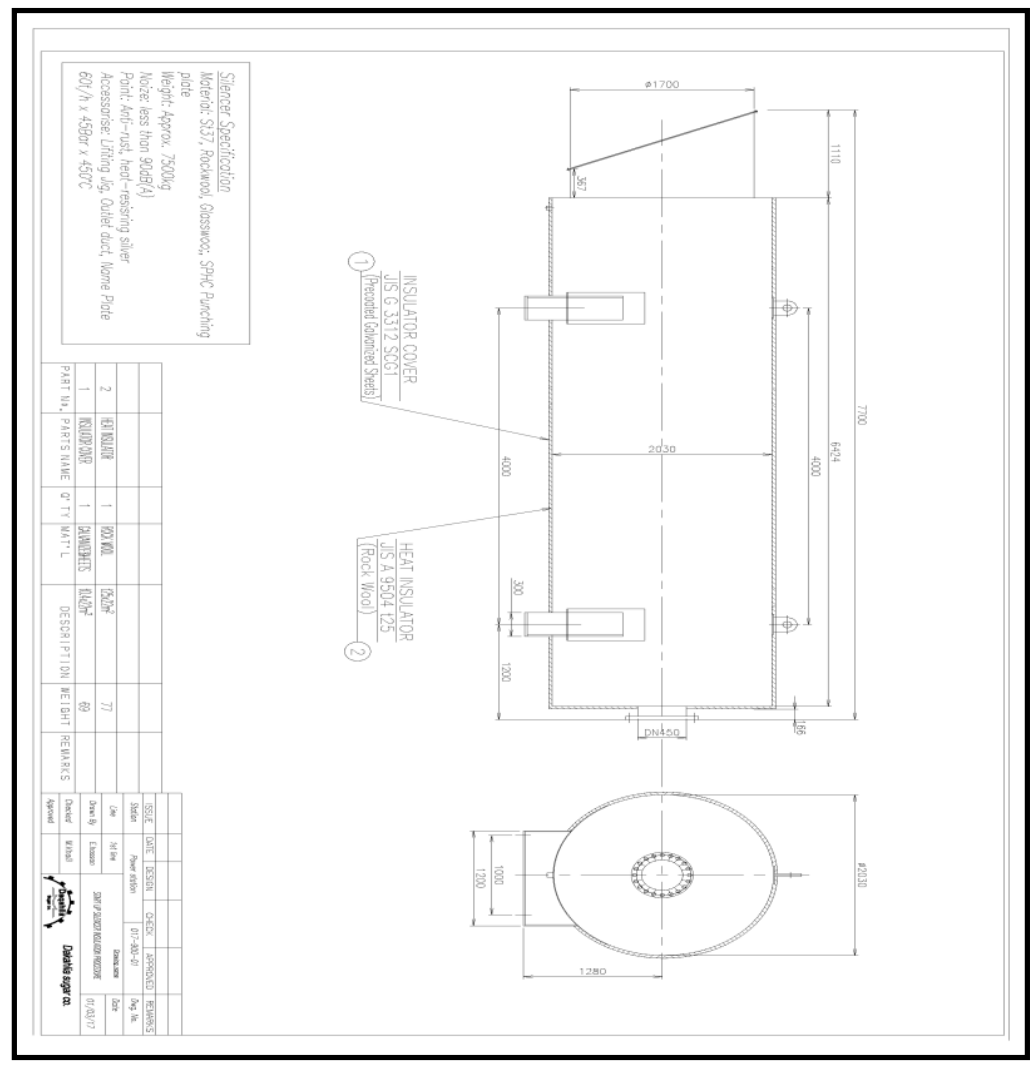

Fig. (5). The covering of soot blower station to decrease the sound level pressure

\section{Conclusion and Recommendations}

The results of this study indicated that the workers at the two factories were exposed to high noise levels during working hours. 
The sound pressure level measured in the old plant is higher than the new plant; due to the old machines and the poor maintenance. Several control measures are suggested to decrease the noise levels such as designing, fabricating and using quieter machines to replace the noisy ones. Also, proper lubrication, better maintenance of machines, installing sound proof chambers in noisy machines, guarding the parts with sound-absorbing materials are also effective methods of noise control. Reducing the noise produced from a vibrating machine can be achieved by vibration damping i.e. making a layer of damping material (rubber). Using silencers is also effective methods to control noise from automobiles, ducts, exhausts etc. and convey systems with ends opening into the atmosphere and using glass wool or mineral wool covered with a sheet of perforated metal for the purpose of mechanical protection.

\section{References}

ACGIH: 2000, 'Threshold Limit Values for Chemical Substances and Physical Agents and Biological

\section{Al-Idrisi, M., Jamil, A. T. M., Al-Jifry, M. S., Jifri, M. A. and} Erturk, F.: 1990, 'Evaluation of noise stresses in Jeddah industrial estate', J. Environ. Sci. Health A 25(8) 873-896.

B\&K: 1978, Application Manual for Acoustic Noise Equipment, Bruel and Kjaer, Naermark, Denmark.

B\&K: 1982, Noise Control: Principles and Practice, Bruel and Kjaer, Naerum, Denmark.

Bies, D. A. and Hansen, C. H.: 1985, Engineering Noise Control, Chapman and Hall, London.

Van deer poel, H. Schiweek, T. Schwartz "Sugar technology beet and cane sugar manufacture ", 4thed. Verlag Dr. Albert .b.k.c, Berlin 1998.

C.H.I version. Revised by D.L. Stewart, "beet - Sugar technology", The Environment -noise, pp. 673- PP 676", $3^{\text {rd }}$, Ed, USA, 1982. 
A.M. Eslam, "Pollution problem of the times ", Series world of knowledge, Kuwait, 1990.

Egyptian Environmental Law No 4; 1994.

European Environment Agency, Noise Inventory; Guidebook, 2005.

El Nagreedy Essam, 2011," Air control pollution from beet sugar factories" , Master Degree, Thesis presented to Sugar Technology Research Institute, Assiut University.

Unified Labor Law No.12 of 2003 fifth book Occupational health and safety and secure work environment.

Environment Protection Agency, "Noise pollution ", 2013.

WHO, world health organization, "Noise pollution ".2013.

International Labor Organization (ILO), Reports on Occupational Safety and Health, 2001.

Noweir, M. H., Moslehi, M., Hussein, M. and Nofal, L: 1985b, 'Noise exposure as related to nonauditory health conditions among Egyptian textile workers', Bull, H. Inst. Publ. Health 15, 53-76(Suppl.)

OSHA (1981): 1986, 'Final Regulatory Analysis for the Hearing Conservation Amendment. Reported in Noise Induced Loss of Hearing', Morbidity and Mortality Weekly Report, 28 March, Vol. 35, No. 12, PHS, U.S. Department of Health and Human Services.

Egyptian standard specifications No 358 / 2005 and European standard specifications for white sugar production.

World Bank, 1995."Industerial pollution prevention and Abatement ;sugar Manufacturing "Draft Technical Back Document. Environment Department, Washington ,D.C.

Assessment and Control of Noise Pollution in Mining Industry, Proceedings of National Seminar held by Institution of Engineers at Madras, 1989. 
Environmental Noise Pollution and its Control, Proceedings of Specialist Course, Institution of Engineers, Roorkee, India 1992.

Industrial Safety and Pollution Control Handbook, Associate (Data) Publishers Pvt., Secunderabad, 1991ed.

Sugar world magazine, sugar integrated industry company Egyptian, SIIC, 2016.

Madbuli H. Noweir, and A.T.Jamil,2003,Noise pollution in textile, printing and publishing industries in Saudi Arabia ,Environment monitoring and Assessment 83:103-111, 2003.

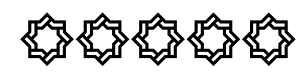




\section{الإذص العربي}

\section{التلوث الضوضائي؛ تقييم وهراقبة في صناعة سكر البنجر}

\section{هممد أبو القاسم هممد 1، رجب السيد ربيعي 1، هممد هممود حافظ 2-عصام عبد الفتاح أبو زيد النجريدي رويدي}

\section{اكلية الهندسة قسم الفلزات والتعدين. جاهعة أسيوط.

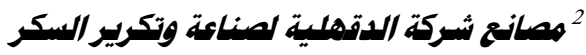

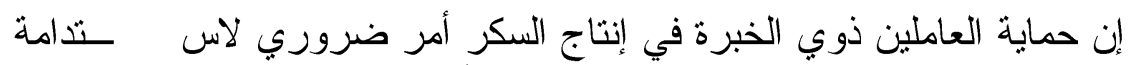

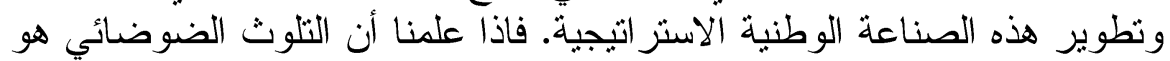

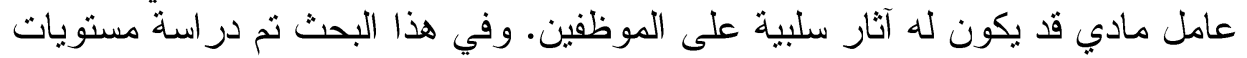

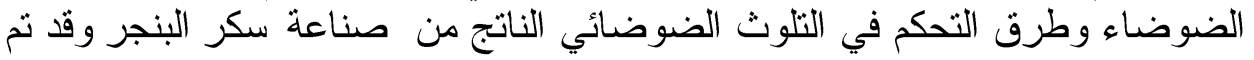

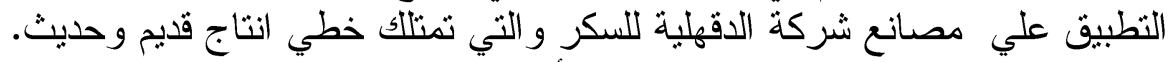

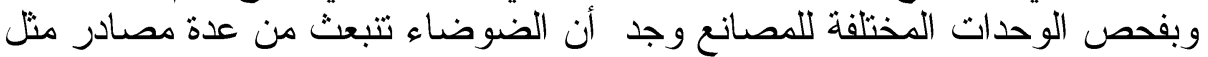

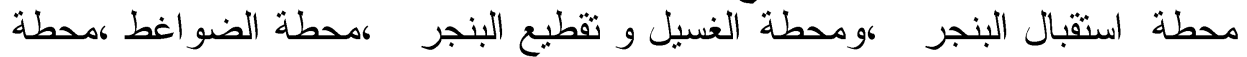

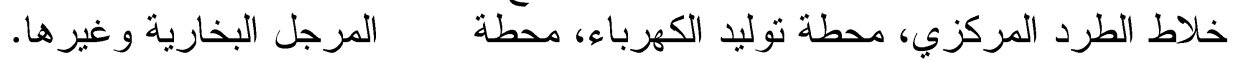

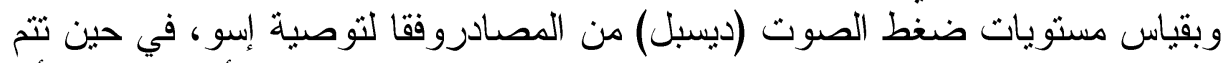

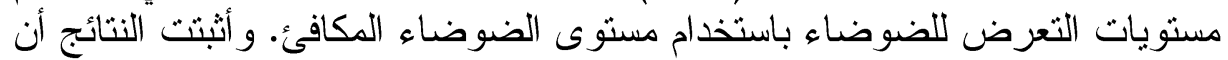

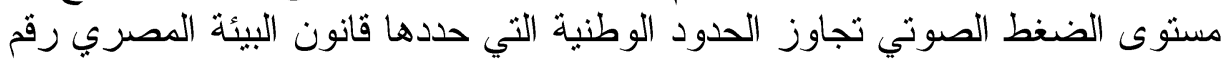

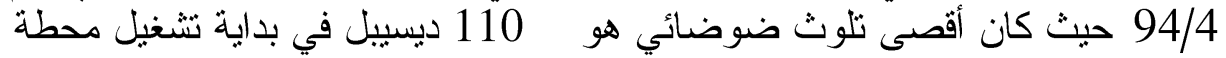

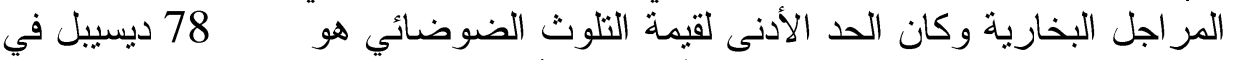

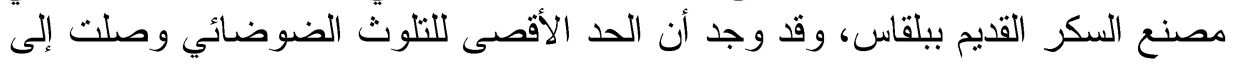

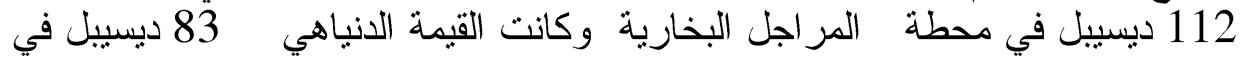

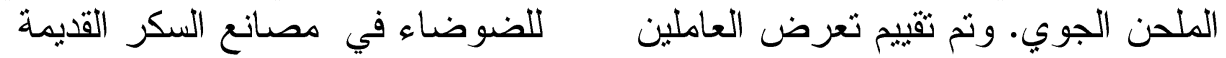

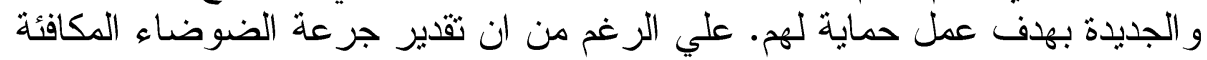

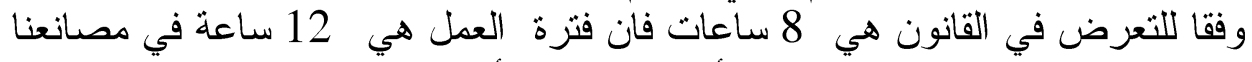

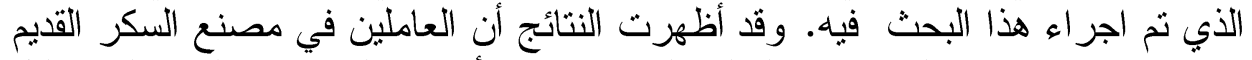

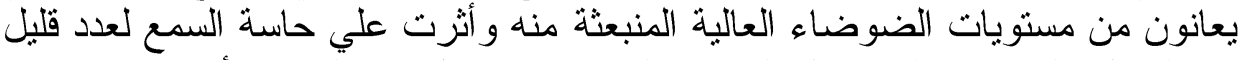

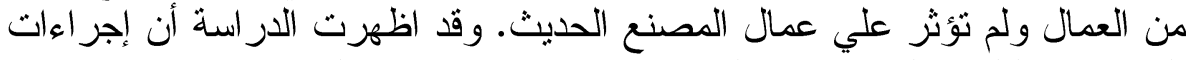

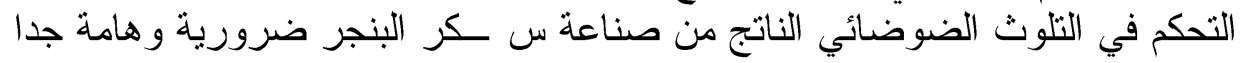
وخاصة من مصنع السكر القديم. 